Danijela Rogina

Josip Juraj Strossmayer University of Osijek Faculty of Civil Engineering and Architecture Osijek 31000 Osijek, Croatia drogina@gfos.hr
Ivana Šandrk Nukić

Josip Juraj Strossmayer University of Osijek

Faculty of Civil Engineering and Architecture Osijek 31000 Osijek, Croatia isandrknukic@gfos.hr
JEL: R11, R14, M19

Review article

https://doi.org/10.51680/ev.34.1.15

Received: May 5, 2020

Revision received: August 31, 2020

Accepted for publishing: September 4, 2020

This work is licensed under a

\title{
THE ROLE OF FINANCIAL VIABILITY IN SUSTAINABILITY AND THE INCREASE OF GREEN ROOFS AS ELEMENTS OF GREEN INFRASTRUCTURE
}

\begin{abstract}
Purpose: As sustainability is quickly becoming a predominant concept at the heart of the $21^{\text {st }}$ century living and thinking, as well as planning for the near future, it has become obvious that financial viability is one of its core determinants. The aim of this paper has been to study the prospects of greater implementation of green infrastructure (GI) and especially green roofs (GR) in Croatia.

Methodology: Theoretical framework is based on the relevant literature review, which has been conducted using qualitative methods of analysis, synthesis, comparison, induction and deduction. The empirical part of the study has been conducted as a survey amongst the civil engineering students, using questionnaire as the survey instrument.

Results: The theoretical part of the research identified the relevance of costs in GI implementation and its social and economic effects, circularity principles and EU funding options. Empirical findings indicate that the majority of Millennials from the sample find the implementation of GI to be financially demanding. Moreover, they are largely unaware of the availability of EU funding for such purpose and find the frugality aspect of green roof implementation very important.
\end{abstract}

Conclusion: It is acknowledged that financial viability is inevitable when considering the implementation of GI. The level of environmental awareness among Croatian Millennials is satisfactory. However, considering they were not sufficiently aware of the EU funding available for this purpose, there is a need to raise awareness among this population segment, as they are future decision-makers.

Keywords: Millennials, green roofs, green infrastructure, EU funding, sustainable development, spatial planning

\section{Introduction}

According to Adams (2006), the concept of sustainability implies that it is possible to achieve economic growth and industrialization without causing environmental damage.
In following decades, mainstream sustainable development thinking was progressively developed through documents such as: the Brundtland Report (1987) and the UN Conference on Environment and Development whose proclaimed principles includ- 
ed the precautionary principle and the polluter pays principle, national government planning, as well as wider engagement from leaders and non-governmental organisations.

The Brundtland Report defined sustainable development as the one "that meets the needs of the present without compromising the ability of future generations to meet their own needs" (1987, p. 43) and by doing so it managed to capture two fundamental issues: the problem of the environmental degradation that usually accompanies economic growth on the one hand and the need for such growth to alleviate poverty on the other.

This definition positioned the idea of finance and economy in the heart of the concept as it contributed to awareness raising about the issue (Davis et al., 2012) and by doing so it also brought into focus problems relating to sustainability in the context of economic growth and continuous human progress.

When considered from the aspect of urban development, the 21st century is defined by the increase in urbanisation, in particular in Europe, with the loss and degradation of urban and peri-urban green space as one of the main causes of adverse effects on the urban environment, ecosystems as well as human health and well-being (Tzoulas et al., 2007). These negative effects can be mitigated by enhanced implementation of green infrastructure in the urban environment.

In this paper, economic and environmental challenges are considered. These challenges have been recognised by the current EU leadership and the latest EU strategy for management of environmental and economic challenges, the European Green Deal, was developed as a response to them. The Deal can be seen as a new growth strategy that aims to transform the EU into a fair and prosperous society, with a modern, resource-efficient and competitive economy where there are no net emissions of greenhouse gases in 2050 and where economic growth is decoupled from resource use. While doing so, this Deal aims to protect, conserve and enhance the EU's natural capital and protect the health and well-being of citizens from environment-related risks and impacts, with green infrastructure as one of the key elements of these solutions (European Commission, 2019).

The paper is structured as follows: it begins with an Introduction, which is followed by a chapter explaining the methodology and methods used. The next chapter provides theoretical framework for socio-economic aspects of sustainable urbanisation. This chapter elaborates the financial viability of green infrastructure, especially the green roofs, addresses the relation between green infrastructure and sustainable urbanisation, indicates negative aspects of greening the urban areas and explains the role of recycling and upcycling. In chapter four, a regulatory and financial framework for sustainable urbanisation is considered. Chapter five contains the results and discussion on Millennials' inclinations regarding the cost of green infrastructure implementation in Croatia. Final remarks as well as recommendations for future research are presented in the conclusion.

\section{Methodology and methods used}

Millennials, also known as generation Y, represent a demographic segment of people born between the early 1980s and the late 1990s. They represent $24.05 \%$ of total population in Croatia and will be entering the workforce by 2022 (Galetić et al., 2016). Millennials are considered an influential demographic segment, which is why the research sample was drawn from this population.

The research has been conducted as a survey, by using a questionnaire comprising closed-end questions inquiring about the importance of green infrastructure when choosing one's living and working environment and the importance of environmental issues and climate change. A 5-point Likert scale (1 - not important, 5 - very important) was used to measure the respondents' opinions. In addition, the questionnaire included open-ended questions to collect information about the financial aspect of green roof installation. Lastly, the questionnaire included various background questions used to determine the individual characteristics of the respondents i.e. gender, student status, date of birth. The optimal, estimated time for the questionnaire to be filled in was approximately 10-15 minutes. The questionnaire was distributed both electronically and on paper to reduce the risk of low response rate.

This paper also presents a review of the literature regarding the frugality or thriftiness aspects in the concept of sustainability and green infrastructure implementation. Using scientific methods of analysis, synthesis, comparison, induction and deduction, the paper draws on the relevant academic 
body of knowledge and looks at available EU funding and strategies.

\section{Socio-economic aspects of sustainable urbanisation}

"Spatial planning refers to the methods used largely by the public sector to influence the future distribution of activities in space. It is undertaken with the aims of creating a more rational territorial organisation of land uses and the linkages between them, to balance demands for development with the need to protect the environment, and to achieve social economic objectives.

Spatial planning embraces measures to co-ordinate the spatial impacts of other sectoral policies, to achieve a more even distortion of economic development between regions than would otherwise be created by market forces, and to regulate the conversion of land and property uses." (European Commission, Directorate-General for Regional and Urban Policy, 1997).

From this statement, it can be seen that the organisation of land uses aims to achieve a balance with the environment protection while achieving socioeconomic objectives. As such, spatial planning is a valuable tool in achieving a goal of sustainable urbanisation as it manages, organises and creates new opportunities for various urban uses and activities.

There are various types of land and space uses. From the aspect of frugality in urbanisation, it is especially interesting to emphasize temporary uses. They have become an established tool in European cities for reactivating vacant sites and providing space for financially weak users. They can be a true win-win situation for users, owners and the authorities if the interests of different stakeholders are taken into account and structural givens adapted to low-budget investments (Ziehl \& Oßwald, 2015).

Furthermore, the redevelopment of brownfield land is regarded as an essential component of sustainable urban regeneration (Doick, 2006) and can be seen as an excellent indicator of sustainability of urban spaces.

Ziehl and Oßwald (2015) discuss possible scenarios for adaptation of buildings and brownfield sites using the term "second-hand spaces", often found within the scope of temporary uses. This concept emphasizes the sustainable effects of temporary uses on urban development relying on "alterna- tive practices like sharing, do-it-yourself, collective self-organization, try-outs, recycling and flexible operation". Through low-budget interventions, temporary use, programming and prototyping such spaces could not only be reclaimed and regenerated but also upcycled - creatively reinvented with minimal use of resources to achieve spaces with new and improved use, greater value, better quality and benefits for the community. This illustrates that frugality is at the core of the sustainability of urban space uses and can produce excellent results.

\subsection{Financial aspects of green roofs}

From the public and developers' point of view, GR often require substantial upfront costs (installation costs) but also very often significant maintenance costs. In order to test this common opinion, research done by Amir et al. (2020), relying on studies conducted worldwide, analysed barriers to GR adoption. The findings reveal that high initial costs and lack of awareness and knowledge are the most significant barriers to overall GR installation, while installation-related challenges and structural damage concerns are the least significant. Their conclusions suggest that the legislative enforcements with financial incentives and emphasis on the improvement of knowledge and awareness are the key measures that will ultimately lead to effective and widespread implementation of GR systems (Amir et al., 2020).

This is consistent with the results of another recent study (Liberalesso et al., 2020), which found that incentives promote and facilitate the adoption of green infrastructure by private investors. The same authors indicate that quantified benefits of GR may indeed not compensate for their high implementation costs, discouraging building owners to invest in them. However, they state that there is a mismatch between the economic/social/environmental value of green infrastructure and the financial analysis.

Additionally, Bianchini and Hewage (2012) argue that inclusion of the social dimension of green roofs improves the value of GR investments. They assessed the Net Present Value (NPV) per unit of area of a green roof by considering the social costs and benefits that green roofs generate over their lifecycle. Their results indicate that green roofs are short-term investments in terms of net returns and that the probability of profits from such investments is much higher than the potential financial 
losses. They conclude that installing a green roof is a low-risk investment.

The recent research conducted by Godyn et al. (2020) focused on unresourceful usage of rainwater. The results of their study show that this serious problem of urban living can be successfully mitigated by the installation of GR. Additionally, the research analysed the efficacy of GR investments measured by the rate of return and the payback period. They found that the proposed GR concept of rainwater management can potentially bring savings of around $9 \%$, and that the investment can be recovered within 12 years.

Thriftiness should be prioritized in any investment, but in the case of GI investments this is necessary not only because of budget restrictions but also as an important notion of a larger narrative that embraces fixing, reusing and incorporating elements of previous infrastructure or landscape, i.e. a narrative that something is created out of choice rather than out of necessity or due to resource limitations. Through community gardening, car-sharing, coworking, food cooperatives and waste recycling, urban dwellers develop innovative, alternative or entrepreneurial ways to challenge resource-heavy ways of managing, developing and living in the city (Herman et al., 2018). Herman et al. (2018) used case studies of three parks in Portugal and examined how the success rate and the current state of these public green areas correlate with the amount of financial resources invested in each of the projects analysed. The success rate of a place was established based on user activity observations, user counts and questionnaires. The results of their study indicate that low-budget strategies can be as effective, popular and sustainable as resource- and finance-heavy designs in creating valuable green infrastructure.

\subsection{Green infrastructure and sustainable urbanisation}

Green infrastructure is one of the key elements of sustainable urbanisation. It is a concept addressing the connectivity of ecosystems, their protection and the provision of ecosystem services, while also addressing mitigation and adaptation to climate change. Green infrastructure helps ensure the sustainable provision of ecosystem goods and services while increasing the resilience of ecosystems. The concept is central to the overall objective of ecosystem restoration, which is now part of the 2020 biodiversity target (European Commission, 2010).

As presented in Figure 1, there are three potential categories of green infrastructure assets.

\section{Figure 1 Potential assets that make up green infrastructure grouped into three scales}

\begin{tabular}{|c|c|c|}
\hline $\begin{array}{l}\text { Local, neighbourhood and village } \\
\text { scale }\end{array}$ & Town, city and district scale & $\begin{array}{l}\text { City-region, regional and national } \\
\text { scale }\end{array}$ \\
\hline $\begin{array}{l}\text { - street trees, verges and hedges } \\
\text { - green roofs and walls } \\
\text { - pocket parks } \\
\text { - private gardens } \\
\text { - urban plazas } \\
\text { - town and village greens and } \\
\text { - local rights of way } \\
\text { - pedestrian and cycle routes } \\
\text { - cemeteries, burial grounds and } \\
\text { churchyards } \\
\text { - institutional open spaces } \\
\text { - ponds and streams } \\
\text { - small wcodlands } \\
\text { - play areas } \\
\text { - local nature reserves } \\
\text { - school grounds } \\
\text { - sports pitches } \\
\text { - swales (preferably grassed), } \\
\text { ditches } \\
\text { - allotments } \\
\text { - vacant and derelict land }\end{array}$ & $\begin{array}{l}\text { - business settings } \\
\text { - city/district parks } \\
\text { - urban canals } \\
\text { - urban commons } \\
\text { - forest parks } \\
\text { - country parks } \\
\text { - continuous waterfronts } \\
\text { - municipal plazas } \\
\text { - lakes } \\
\text { - major recreational spaces } \\
\text { - rivers and floodplains } \\
\text { - brownfield land } \\
\text { - community woodlands } \\
\text { - (former) mineral extraction sites } \\
\text { - agricultural land } \\
\text { - landfill }\end{array}$ & $\begin{array}{l}\text { - regional parks } \\
\text { - rivers and floodplains } \\
\text { - shorelines } \\
\text { - strategic and long distance trails } \\
\text { - forests, woodlands and community } \\
\text { forests } \\
\text { - reservoirs } \\
\text { - road and railway networks } \\
\text { - designated greenbelt and strategic } \\
\text { gaps } \\
\text { - agricultural land } \\
\text { - national parks } \\
\text { - national, regional or local } \\
\text { landscape designations } \\
\text { - canals } \\
\text { - common lands } \\
\text { - open countryside }\end{array}$ \\
\hline
\end{tabular}

Source: EEA Technical report No 18/2011 (European Commission, 2010) 
All of these assets are relevant for sustainable urbanisation as urban green spaces provide immediate access to the "experience of nature" that comes with various aspects and elements of the landscape. Trees and other vegetation, animals, wind and flowing water, and changes of seasons positively affect human health and well-being. Quantity and quality of green spaces situated in the vicinity of urban settlements associate positively with perceived mental health. To fulfil this premise, green spaces have to not only be well designed, with the focus on natural habitats, wildlife and resilient technologies but also be well used and appreciated by the public (Herman et al., 2018).
Green infrastructure usually stands for an intentionally created and managed, novel ecosystems. However, these intentionally and to a degree artificially created ecosystems may be supplemented by naturally originated GI, i.e. spontaneous, wilderness (Lundholm, 2016).

Thus, in broad terms, two types of green infrastructure can be distinguished:

- intentionally created and designed green infrastructure

- unintentionally/spontaneously created wild green infrastructure.

\section{Figure 2 Unintentionally/spontaneously created wild green wall infrastructure (image on the left) in Osijek, Croatia and intentionally created and designed green infrastructure - Rozanno Shopping Cen- tre, Italy (image on the right)}
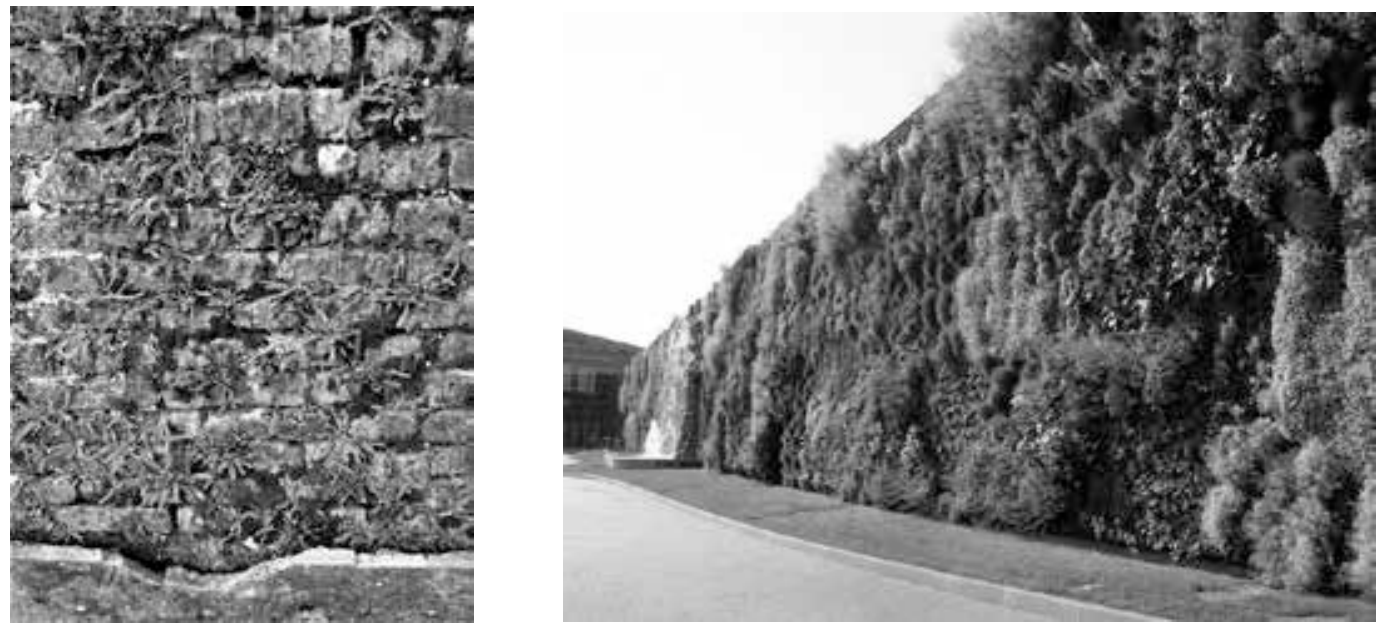

Source: Authors' own image (on the left) and image of Rozanno Shopping Centre (on the right) ${ }^{1}$

\subsection{Negative aspects of greening the urban areas}

By appreciating the view that circular economy ${ }^{1}$ is a model aiming to decouple the environmental pressure from economic growth (Ghisellini et al., 2015) and by integrating GR and GI technologies early into the urban planning processes, urban planning will have an important role to play in optimizing the circular/looping patterns in highly urbanised areas.

Williams (2019) stated that the urban environment presents 58 challenges to looping actions across eight themes. Addressing these challenges could enable looping actions across resource types in cities.

1 https://www.flickr.com/photos/42581411@No4/5764655685 
Figure 3 Challenges of looping activities across resource types

\begin{tabular}{|c|c|c|c|c|c|c|c|c|c|}
\hline \multirow[b]{2}{*}{ Theme } & \multirow[b]{2}{*}{ Challenge } & \multicolumn{2}{|c|}{ Materials, } & \multirow{2}{*}{$\begin{array}{l}\text { Waler } \\
\text { recyeling }\end{array}$} & \multicolumn{2}{|c|}{ Infrastructure } & \multicolumn{2}{|c|}{ Land } & \multirow{2}{*}{$\begin{array}{l}\text { Energy } \\
\text { recoveny }\end{array}$} \\
\hline & & reuse & recycling & & neuse & recycling & reuse & recycling & \\
\hline Socio-cultunt & Existing values $k$ norms & $\mathbf{x}$ & $x$ & $x$ & $x$ & $x$ & & $x$ & \\
\hline \multirow[t]{4}{*}{$\begin{array}{l}\text { Ecoucmic and } \\
\text { financid }\end{array}$} & Financial viability & $\mathbf{x}$ & $x$ & $x$ & $\mathrm{x}$ & $\mathbf{x}$ & $\mathbf{x}$ & $\mathbf{x}$ & \\
\hline & Vested interests and sunk costs & $\mathbf{x}$ & $x$ & $\mathbf{x}$ & $\mathrm{x}$ & $x$ & $\mathbf{x}$ & & $x$ \\
\hline & $\begin{array}{l}\text { Low cost of vingin, finite, now } \\
\text { resources and green feld sites }\end{array}$ & $\mathbf{x}$ & $x$ & & $\mathrm{x}$ & $x$ & $\mathbf{x}$ & $x$ & $\mathrm{x}$ \\
\hline & Health \& safety risk & $\mathbf{x}$ & $x$ & $\mathbf{x}$ & $x$ & $x$ & & $\mathbf{x}$ & $x$ \\
\hline Enformation & Data availability & $\mathbf{x}$ & $x$ & $x$ & $x$ & $x$ & $\mathbf{x}$ & $\mathrm{x}$ & $x$ \\
\hline \multirow[t]{2}{*}{ Regulatory } & $\begin{array}{l}\text { Lack of joined-up supportive } \\
\text { framework }\end{array}$ & $\mathbf{x}$ & $x$ & $x$ & $\mathrm{x}$ & $x$ & $\mathbf{x}$ & $\mathbf{x}$ & $x$ \\
\hline & Lack of common standards & $\mathbf{x}$ & $\mathbf{x}$ & $\mathbf{x}$ & $x$ & $\mathbf{x}$ & $\mathbf{x}$ & $\mathbf{x}$ & $\mathrm{x}$ \\
\hline \multirow[t]{2}{*}{ Political } & Lack of longeterm political support & $\mathbf{x}$ & & $\mathbf{x}$ & $\mathrm{x}$ & $x$ & $\mathbf{x}$ & & \\
\hline & Competing priorities & $\mathbf{x}$ & $x$ & $\mathbf{x}$ & $x$ & $x$ & $\mathbf{x}$ & $x$ & $x$ \\
\hline \multirow[t]{3}{*}{ instritutional } & Instifutional Inertia & $\mathbf{x}$ & & $\mathbf{x}$ & $x$ & & $\mathbf{x}$ & & \\
\hline & Lack of institutional capacity & $\mathbf{x}$ & $\mathrm{x}$ & $x$ & $x$ & $x$ & $x$ & $x$ & $x$ \\
\hline & Cities limixed powers & & & $x$ & $x$ & $x$ & $\mathbf{x}$ & $x$ & $x$ \\
\hline Technicat \& Desigut & Socio-technical lock-in & $\mathbf{x}$ & $x$ & $x$ & $\mathrm{x}$ & $x$ & & & $x$ \\
\hline
\end{tabular}

Source: Williams (2019)

Additionally, while there is much to gain with greening the urban areas, there are some negative aspects to be considered, too.

Greening cities, namely installing new parks, green roofs and gardens or planting trees along the streets, undoubtedly contributes to an increase in wellbeing and enhances the attractiveness of open spaces in cities. But, one should bear in mind that it can lead to environmental gentrification as this action is very often a market-driven endeavour targeting middle class and higher-income groups sometimes at the expense of less privileged residents (Haase et al., 2017).

According to Rigolon and Nemeth (2018), environmental gentrification, or the influx of wealthy residents to historically deprived neighbourhoods due to new green infrastructure, is an increasingly common phenomenon around the globe with investments in large green infrastructure projects, such as New York High Line, have contributed to displacing long-term low-income residents. Therefore, many consider environmental gentrification to be an important environmental justice issue that definitely warrants further research, as the increase in the desirability of a greener urban environment is likely to include gentrification as one of the less desirable outcomes. Consequently, according to Haase et al. (2017), the future functions and features of greening cities have to be discussed more critically including a greater awareness of social impacts.

Diep et al. (2019) highlight some of the limits in the current conceptualisation and implementation of urban green infrastructure, particularly in informal settlements, suggesting that a better understanding of the range of socio-political conditions would facilitate GI implementation. In situations when tensions between social and ecological systems occur, e.g. concerning water management issues, it is important to embrace and involve community initiatives and in that way further contribute towards the sustainability, innovation, as well as reduction of maintenance costs while demonstrating a connection between top-down structures and everyday practices.

\subsection{Recycling and upcycling as frugality tools of sustainable urbanisation}

The widely accepted and known term of recycling denotes a process that involves converting materials and products into new materials of lesser quality, which is also called downcycling, due to the decrease in quality (Kay, 1994).

Recycling has various aspects and there are various ways of implemented it. When considered in terms of GI, one of its key characteristics is a positive contribution towards the innovation of some of the elements of traditional GI. For example, one 
of the most interesting and at the same time most prominent innovations represents changes in the construction of "conventional" green roof installation by the inclusion of recycled materials i.e. aggregates or demolition waste. They can be used as part of the green roof substrates to replace original and fresh natural resources.

In addition to the positive contribution of recycling towards the increase in GI implementation and its thriftiness, this concept can be also applied to the urban uses. Disused urban infrastructure and "waste" materials can be reused or recycled for new purposes. These technospheric resource reservoirs offer an opportunity for more sustainable development (Williams, 2019) that can provide a substantial reduction in funding required for any urban development.

In contrast, the term upcycling is not so common. Upcycling as a concept was initially embraced by the upcycling pioneer Reiner Pilz, a mechanical engineer from Germany. In an interview, which was first published in Salvo magazine in 1994, he talks about using antiques and salvaged materials, restoring them and then using them as something else of greater value and by doing so increasing their initial value.

Upcycling is regarded as one of the most sustainable circular solutions, positioned between reuse and recycling. Upcycling typically requires little energy and resource input and can eliminate the need for a new product (Herman et al., 2018).

The principle can be also applied in green infrastructure implementation. In green roof constructions, particularly in smaller roofs, where a wooden material used in making a pallet, a flat transport structure, can be used to make an entire shed or a pet home with a green roof on top and so create a new product or a green infrastructure element with an increased value compared to the initial product.

Unused spaces, just like objects and waste, can be creatively changed, reinvented with little resource input through a circular solution of upcycling (Herman et al., 2018).

Through the lenses of upcycling, designers (including landscape architects) could explore ways to create places of greater quality and significance (especially to the local community) while making only the most urgent and necessary changes that would consume minimal amounts of new resources. To achieve this, careful studies of the pre-existing strengths of a place, the ways it is used and anticipation of the chances of planned adjustments being accepted or disregarded by the local community have to be considered. Operating in the schemes of public participation, prototyping (through temporary uses and low budget interventions) and upcycling can with certainty lead to projects that use fewer resources, are devoid of significant errors and provide users with space that fits their needs and is "tailor-made". Upcycled spaces that are planned and programmed in the framework of low-budget design should also be multifunctional-providing local citizens with a variety of ecosystem services. The aim of such a process should be to create synergies that increase the overall benefits provided by the Green Infrastructure (Herman et al., 2018).

Therefore, upcycling can be the next step towards sustainability of resources. We do not just use or reuse and recycle resources with greater effectiveness; we improve the natural world as we live, create and build (McDonough, 2013).

In conclusion, recycling and upcycling are two relatively new concepts that represent a particularly useful element of sustainability, as they represent a valuable link in a chain of looping activities that will contribute towards the continuous evolution of green infrastructure and urban environment that satisfies human needs.

\section{Regulatory and financial framework of sustainable urbanisation}

In amongst many challenges in green infrastructure development, the financial aspect is one of the key ones. Whether it is due to insufficient information or wrong perception of GI, it has been mostly considered as being too expensive to implement or being an extra cost on top of the cost already necessary, this aspect is seen as one of the main obstacles to wider use of GI elements.

As the sustainable development continued to be one of the main concerns of contemporary living, provisions were made within the current financial frameworks that can positively contribute towards greater use of GI on an individual level as well as the level of public authorities. European Union has dedicated several strategies and action plans and secured funding for these purposes. 
Furthermore, various initiatives such as URBACT, Urban Development Networks (UDN), Covenant of Mayors and Danube strategy were established, representing a valuable contribution to the promotion of green infrastructure.

With some of them comprising over 500 cities/urban areas across the EU, assuming responsibility for implementation of actions, promotion of dialogue, facing similar challenges, exchanging good ideas and supporting initiatives and information exchange related to sustainable and urban development strategies, it is obvious that they are an important factor in improvement and promotion of innovation in sustainable development.

In order for all major existing strategies, legislation and initiatives to achieve their mission and vision, especially those related to sustainable development and environmental protection, various programmes for funding have been established. These programs, in most cases, do not have a singular aim or goal but usually have several priorities per announcement. At least one in the list compiled is in some way compatible with GI and sustainable development activities.

Member States currently have an opportunity to support Green Infrastructure through programs integrated into their development strategies and cofinanced from the Structural Funds (the European Regional Development Fund and European Social Fund), the Cohesion Fund, the European Maritime and Fisheries Fund, the European Agricultural Fund for Rural Development, LIFE+ and the research funding programmes. Funding for climate change mitigation and adaptation could also provide significant co-benefits for Green Infrastructure, given the carbon storage, erosion and flood control services of many ecosystems.

The Commission and the European Investment Bank (EIB) have established the Natural Capital Financing Facility (NCFF). The NCFF will finance investments in natural capital projects, including Green Infrastructure, which generate revenues or save costs and contribute to nature, biodiversity and climate change adaptation objectives. The NCFF is open to public and private entities, where appropriate cooperating in partnerships. Investments could, for example, focus on ecosystem restoration projects as insurance against floods or draughts or to improve water quality.

Given the limitations of public funds, it would be desirable for the private sector to play a more active role in financing Green Infrastructure. From the European Union's point of view, green infrastructure provides possibilities to be used as insurance for economic development against climate change effects, in particular as an excellent tool for the green economy and building upon economic advantages of restoration (such as the increase in land values of a restored area and its surroundings compared with intensively exploited or degraded agricultural, urban or industrial areas). Green Infrastructure can also provide financing opportunities linked to innovation, such as innovative planning approaches, the design of urban elements enhancing biodiversity, and all combinations of technologies enhancing ecosystem services.

The UNHCR Agenda $2030^{2}$ is a plan of action for people, planet and prosperity, which recognises that eradicating poverty in all its forms and dimensions, including extreme poverty, is the greatest global challenge and an indispensable requirement for sustainable development. With its 17 sustainable development goals, it balances the three dimensions of sustainable development: the economic, social and environmental, which further confirms the central position of financial frugality in the concept of sustainable development.

The EU provides funding for environmental projects and initiatives through several funds. The most important ones are listed below:

- Eco-Innovation Fund - aims to support innovation in SMEs and to improve competitiveness

- INTERREG IVC Fund - provides funds for interregional cooperation

- Horizon 2020

- LIFE+ (includes operating grants to European environmental NGOs) - this is the EU's instrument for the environment

- European Structural Funds (SF) include:

- European Regional Development Fund (ERDF), which provides support for infrastructure and job creation

- European Social Fund (ESF), which assists the unemployed and disadvantaged sections of the population

- European Agricultural Guidance and Guarantee Fund (EAGGF), which assists

2 UNHCR (2015). Transforming Our World: The 2030 Agenda for Sustainable Development. Canberra: UNHCR Regional Representation Publishing. 
with the development and structural adjustment of rural areas

- Financial Instruments for Fisheries Guidance (FIFG), which supports restructuring in the fisheries sector.

- Cohesion Fund (CF) - aims to decrease economic and social disparities

- Instrument for Pre-Accession Assistance (IPA) that has subsequently transformed into Interreg programmes

- European Neighbourhood and Partnership Instrument (ENPI) - supports the European Neighbourhood Policy, which aims to strengthen the European neighbourhood through improving stability and security

- European Fisheries Fund (EFF) - provides funding to the fishing industry and coastal communities

- European Agricultural Fund for Rural Development (EAFRD) -aims to help strengthen the EU's rural development policy in line with the Common Agricultural Policy (CAP)

From the non-exhaustive list above, it is clear that there are plenty of possibilities and options for EU financing. As these programmes have been available to older EU member states for longer, they have naturally achieved better results and gained more experience in successfully applying for funding. However, in spite of being the most recent member state, Croatia has successfully implemented a num- ber of GI projects in new and retro-fit development that have been co-financed by the EU. Some of the many current, successful projects include GI elements such as green walls and roofs, urban green corridors, creation of urban pollinator-friendly areas and parks, etc.

\section{Research results and discussion of Millennials' attitudes regarding the cost of green roof implementation in Croatia}

Despite the myriad examples of good practice across Croatia and Europe, the results of the empirical part of this research, investigating the opinions of a national sample of Millennials, raises concerns regarding their awareness and openness to GR implementation as an element of the modern urban environment. The findings are presented hereinafter.

The initial stage of the research design included the selection of respondents for the empirical part. Next, a review was carried out of the extensive literature on core concepts of sustainability, green roofs and green infrastructure as well as the relevance of their financial aspects. The empirical research was aimed at conducting a "reality check" in the form of gathering opinions of the surveyed Millennials.

Data were gathered from students from November to December 2019, with the phase of analysis and interpretation following immediately after that. A total of 167 civil engineering students filled out the questionnaires. The descriptive statistics of the respondents are shown in the table below.

Table 1 Frequency analysis of the sample

\begin{tabular}{|l|c|c|}
\hline Independent characteristic $\mathbf{N}=\mathbf{x x}$ & Quantity & Percentage \\
\hline \multicolumn{3}{|c|}{} \\
\hline Gender & 78 & 46 \\
\hline Male & 89 & 54 \\
\hline Female & $1988-2000$ & - \\
\hline Year of birth & 15 & 9 \\
\hline \multicolumn{3}{|l|}{} \\
\hline Location of the Faculty & 67 & 40 \\
\hline Zagreb & 33 & 20 \\
\hline Split & 52 & 31 \\
\hline Rijeka & 53 & \\
\hline Osijek &
\end{tabular}

Source: Authors 
The collected data show that $89 \%$ of the respondents are familiar with the concept of green roof and have seen at least one building that has it. Additionally, 67\% of students enrolled in civil engineering faculties think that the implementation of green infrastructure and green roofs, in particular, is financially demanding.

Over $59 \%$ are unaware of EU funding for green infrastructure implementation.

When asked to rate the importance of environmental, financial or social benefits of green roofs, the
Millennials from the sample found very important the frugality aspect of green roofs, such as individual production of energy/food or reduction of utility bills, i.e. the financial aspects of green infrastructure implementation. The most important aspect, however, is reduction of air pollution, closely followed by the production of food or energy (solar panels) and reduction of heating or cooling bills in the third place, with the rest of the environmental benefits ranking at the bottom of the scale.

Figure 4 Evaluation of key green roof financial and environmental benefits

Key green roof financial and environmental benefits

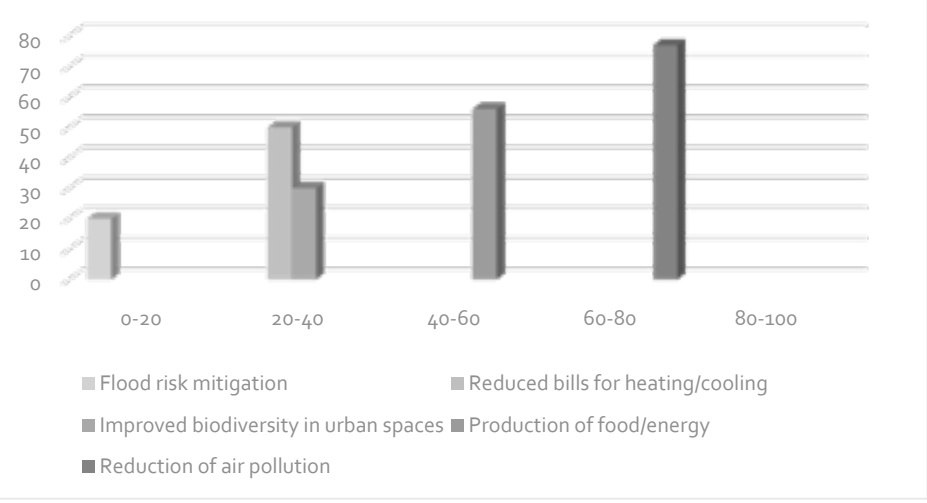

Source: Authors

The results clearly indicate that financial savings are among the most important benefits.

\section{Figure 5 The importance of key urbanisation concepts}

\section{Key urbanisation concepts ranking}

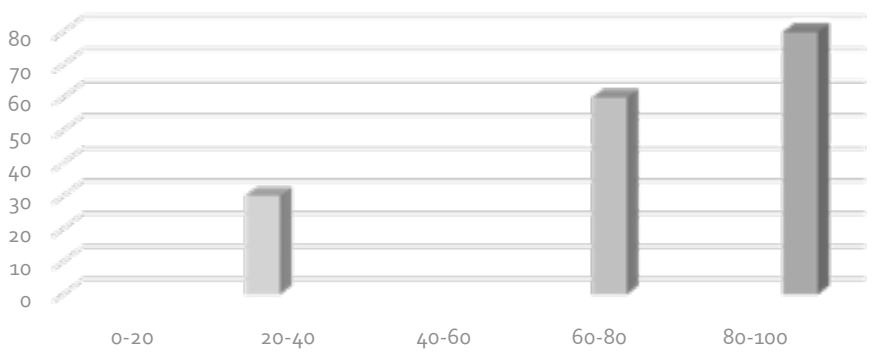

Individual, long-term financial benefit of Gl implementaion

- Individual contribution towards the reduction of climate risks

- Individual contribution towards the sustainable development

Source: Authors 
However, when asked to rate the importance of individual, long-term financial benefits of GR implementation relative to traditional roofing materials, contribution towards the reduction of climate risks and sustainable development, the respondents rated sustainable development as most important to them, followed by contribution towards the reduction of climate risks and financial benefits as least important.

These results indicate that although, in theory, the reduction of climate risks matters to the respondents the most, in practice, financial benefits of green roof implementation, as one of the key tools in the reduction of climate risks ${ }^{3}$, take precedence and make 2 out of 3 top priorities.

Furthermore, it is interesting to note that despite clearly expressing concerns regarding the financial aspect of green roof implementation, the majority of respondents (75\%) expressed unwillingness to apply for such funding. This can be an indicator of the insufficient knowledge or competencies regarding the EU funding process, a hypothesis that authors find only further research could clarify.

\section{Conclusions}

This paper established that when thinking and working towards the sustainability of green infrastructure and increasing the use of green infrastructure elements, green roofs being one of them, it is essential to consider financial viability.

The loss of biodiversity and endangered ecosystems are both global and local challenges. Any progress towards reaping the benefits of green infrastructure depends on the willingness of individuals to implement GI in their (peri)urban environment. This is where the Millennials play an important role, as they have been recognized as tomorrow's decisionmakers.
The empirical part of the study was conducted by means of a survey among the students of all four civil engineering faculties in Croatia. The results suggest that the majority of the surveyed Millennials find that the implementation of green infrastructure, green roofs in particular, is financially demanding. In addition, they have reported that they are largely unaware of the availability of EU funding for such purpose. In addition, they find very important the frugality aspect of green roofs, central to elements such as individual production of energy/food or a reduction in utility bills. It is interesting that the majority of surveyed Millennials expressed unwillingness to apply for EU funding despite the fact that they appreciate the financial benefits of GR. This view can be a sign of the insufficient knowledge regarding the EU funding processes, suggesting that additional efforts are needed to raise awareness about financial tools available to promote GI implementation.

It can be concluded that environmental awareness of the young in Croatia allows us to hope that the application of green infrastructure will make a positive contribution towards mitigation of negative aspects of urbanisation and climate change in the near future. This answers the research question of this study about the prospects of implementation of green roofs in Croatia. However, the results also indicate that the surveyed Millennials' environmental awareness is significantly affected by their financial concerns regarding implementation. Therefore, identifying true motivations behind Millennials' future decisions and actions is an important avenue for future research.

3 European Environment Agency (2011). Green Infrastructure and Territorial Cohesion. The Concept of Green Infrastructure and Its Integration into Policies Using Monitoring Systems, EEA Technical report No 18/2011. Luxembourg: Publications Office of the European Union. 


\section{REFERENCES}

1. Adams, W. (2006). The Future of Sustainability: Re-thinking Environment and Development in the Twenty-first Century.

2. Amir, M., Saeed, R. M., Serdar, D., Sanaz, T. \& Syuhaida, I., (2020). Barriers to green roof installation: An integrated fuzzy-based MCDM approach. Journal of Cleaner Production, 269. https://doi.org/10.1016/j.jclepro.2020.122365

3. Bianchini, F. \& Hewage, K. (2012). Probabilistic social cost-benefit analysis for green roofs: A lifecycle approach. Building and Environment, 58, 152-162. https://doi.org/10.1016/j.buildenv.2012.07.005

4. Brundtland, B. H. (1987). Report of the World Commission on Environment and Development: Our Common Future. Oxford University Press.

5. Davis E., Bowser, G. \& Brown, M. (2012). Creating the Global Leader and the Global Mindset. In Rigling Gallagher, D. (Ed.), Environmental Leadership: A Reference Handbook. Sage Publications.

6. Diep, L., Dodman, D. \& Parikh, P. (2019). Green Infrastructure in Informal Settlements through a Multiple-Level Perspective. Water alternatives - An interdisciplinary journal on water politics and development, 12(2), 554-570.

7. Doick, K., Sellers, G., Hutchings, T. \& Moffat, J. (2006). Brownfield sites turned green: realising sustainability in urban revival. WIT Transactions on Ecology and the Environment, 94, 131-140. https://doi.org/10.2495/BF060131

8. European Commission (2010). European Landscape Convention. http://conventions.coe.int/Treaty/en/Treaties/Html/176.htm

9. European Commission (2019). The European Green Deal. COM 640 final. Publications Office of the European Union.

10. European Commission, Directorate-General for Regional and Urban Policy (1997). The EU compendium of spatial planning systems and policies. Luxembourg: Publications Office of the European Union, p. 24.

11. Galetić, L., Načinović Braje, I. \& Klindžić, M. (2016). Exploring the gap between Millennials' Pay Preferences and Compensation Practices. The Business Review Cambridge, 24(1), 36-43.

12. Ghisellini, P., Cialani, C. \& Ulgiati, S. (2015). A review on circular economy: the expected transition to a balanced interplay of environmental and economic systems. Journal of Cleaner Production, 114, 11-32. https://doi.org/10.1016/j.jclepro.2015.09.007

13. Godyn, I., Grela, A., Stajno, D. \& Tokarska, P. (2020). Sustainable Rainwater Management Concept in a Housing Estate with a Financial Feasibility Assessment and Motivational Rainwater Fee System Efficiency Analysis. Water, 12(1), 1-22. https://doi.org/10.3390/w12010151

14. Haase, D., Kabisch, S., Haase, A., Andersson, E., Banzhaf, E., Baro, F., Brenck, M., Fischer, L., Frantzeskaki, N. \& Kabisch, N. (2017). Greening cities - To be socially inclusive? About the alleged paradox of society and ecology in cities. Habitat International, 64, 41-48.

https://doi.org/10.1016/j.habitatint.2017.04.005

15. Herman, K., Sbarcea, M. \& Panagopoulos, T. (2018). Creating Green Space Sustainability through Low-Budget and Upcycling Strategies. Sustainability, 10(6). https://doi.org/10.3390/su10061857

16. Kabisch, N., Korn, H., Stadler, J. \& Bonn, A. (2017). Theory and Practice of Urban Sustainability Transitions: Nature based Solutions to Climate Change Adaptation in Urban Areas. Springer Open. https://doi.org/10.1007/978-3-319-56091-5

17. Kay, T. (1994). Reiner Pilz - Thinking about Green Future. Salvo NEWS, 99, 11-14.

18. Liberalesso, T., Cruz, C. O., Silva, C. M. \& Manso, M. (2020). Green infrastructure and public policies: An international review of green roofs and green walls incentives. Land use policy, 96.

https://doi.org/10.1016/j.landusepol.2020.104693 
19. Lundholm, J. T. (2016). Spontaneous dynamics and wild design in green roofs. Israel Journal of Ecology and Evolution, 62(1-2), 23-31. https://doi.org/10.1080/15659801.2015.1025511

20. McDonough, W. \& Braungart, M. (2013). The Upcycle: Beyond Sustainability-Designing for Abundance. North Point Press.

21. Rigolon, A. \& Nemeth, J. (2018). We're not in the business of housing: Environmental gentrification and the nonprofitization of green infrastructure projects. Cities, 81, 71-80. https://doi.org/10.1016/j.cities.2018.03.016

22. Tzoulas, K., Korpela, K., Venn, S., Yli-Pelkonen, V., Kamierczak, A., Niemela, J. \& James, P. (2007). Promoting ecosystem and human health in urban areas using Green Infrastructure: A literature review. Landscape and Urban Planning, 81(3), 167-178. https://doi.org/10.1016/j.landurbplan.2007.02.001

23. Williams, J. (2019). Circular Cities: Challenges to Implementing Looping Actions. Sustainability, 11(2). https://doi.org/10.3390/su11020423

24. Ziehl, M. \& Oßwald, S. (2015). Practices in second-hand spaces: Producing value from vacancy. Ephemera, 15(1), 263-277. 